\title{
Effectiveness of Various Factors on Athlete Physical Fitness in Sports Centre West Sumatera, Indonesia
}

\author{
Denas Symond ${ }^{1}$, Hafifatul Auliya Rahmy ${ }^{2}$, Rosfita Rasyid ${ }^{3}$ \\ \{denaspdg@mail.com ${ }^{1}$ \} \\ Department of Nutrition, Faculty of Public Health, Andalas University, Padang, Indonesia ${ }^{1,2}$ \\ Department of Biomedical, Faculty of Medical Andalas University, Padang, Indonesia ${ }^{3}$
}

\begin{abstract}
Athlete's achievements can be achieved with a high level of fitness. This study aims to determine the risk factors for the level of fitness of athletes in the Sport Office and Youth in the West Sumatra Province. This research is analytical with cross sectional design. Samples with purposive sampling method (106 athletes). Data analysis using Chi Square Test, Fisher Exact Test and multiple logistic regression. The fitness level of athletes as much as $78.3 \%$ has good fitness. There is a relationship between BMI / Age $(p=0.013)$ with fitness level and there is no correlation between eating behavior $(\mathrm{p}=1.00)$ and fitness level. Recommended for the next researcher is to examine the effectiveness of nutrition education on athlete's eating behavior and the acceptability of the food menu offered to athletes.
\end{abstract}

Keywords: Athlete's, Fitness, BMI/Age, Eating Behavior, Physical Activity

\section{Introduction}

Sport is a regular and planned activity carried out repeatedly to improve the degree of health and physical fitness. Sports achievements aim to foster and develop sportsmen in a planned, safe and sustainable manner through competition to achieve achievements with the support of science and technology. ${ }^{(1)}$

In general Indonesian sports achievements are still very concerning both at regional and international levels. Various causes can result in decreased performance. In addition to mental, psychological, technical, and strategic problems as well as physical factors, especially endurance and fitness that are less supportive can result in decreased athletes's performance. ${ }^{(2)}$

Physical fitness is the ability of the body to adapt to the physical load given. Physical fitness is influenced by various factors, namely age, gender, genetics, physical activity, rest, and including nutrition. The Sport Development Index (SDI) data in 2006 shows the level of fitness in Indonesia, which is mostly still in the less and very less category $(42.90 \%$ and $37.40 \%)$ and those in the excellent category $(1.08 \%)$ are good $(4,07 \%)$ and moderate $(13.55 \%)$.

Youth Center of Sport is a national sports nursery school, which is used to find and foster sports talent at school age. The Kemenpora report (2014) shows the achievements of the West Sumatra Youth Center Sports athletes from 2011 to 2014 have not won a medal at the Regional Championships, and experienced a significant decline compared to the regional championships in 2010. While at the National Championship, Youth Center athletes were Sport in West Sumatra has also not won medals in 2013 and $2014 .^{(3)}$ 
The preliminary study conducted was obtained from the results of the physical fitness physical fitness test report for Youth Center athletes in West Sumatra in October 2017 showing that the average VO2Max value of athletes was $21.8-64.4 \mathrm{mg} / \mathrm{kg} /$ minute. VO2Max is a person's ability to use oxygen during maximum activity. The higher the VO2Max, the higher the body's resistance when exercising.

The results of preliminary observations made by athletes problems encountered from the nutritional aspect are lazy eating athletes because they tend to get bored with the menu presented so that athletes like to consume food outside the hostel. Apriantono, in the national training centering program stated that there were many reports about athletes who were less disciplined about eating. If food is considered to be less than satisfying, they consume food directly outside the accommodation which is not necessarily nutritious enough for athletes.

The optimal nutritional condition of athletes cannot be formed in a short time but slowly through a good eating habit. Athletes must have the opportunity to learn about food, nutrition and health and apply it to form healthy eating behaviors. Thus the effort to get high-quality athletes in sports, investment in nutrition is very important.

Then the results of recall intake carried out on 5 athletes, the average carbohydrate consumption of athletes was only 53\% of total energy, protein $56 \%$ of total energy and fat consumption of 3 athletes over $39 \%$ of total energy. If seen from the Body Mass Index according to age (BMI-for-Age) 3 athletes have normal BMI / Age, 1 thin person and 1 fat person. Because of this there is an imbalance in nutrition and nutritional status of athletes.

Based on the description above, researchers are interested in knowing the risk factors for the fitness level of athletes in the West Sumatra Youth Center of Sports Allegiance in 2018.

\section{Method}

The study design used was a cross sectional study, where the dependent variable (fitness level) and independent (eating behavior, BMI / Age, energy intake, carbohydrate, fat and protein, physical activity). This research was carried out at the Youth Center of Sport in West Sumatra Province in 2018. The population in this study were all teenage athletes in the Youth Center of West Sumatra Sports Law with a total of 154 people. Based on the calculation results, a sample of 106 people was obtained. The sampling technique was purposive sampling.

Data collected are primary and secondary data. Primary data is data obtained directly from the object of research which includes measurement of nutritional status, interviews with questionnaires covering data on respondent characteristics, eating behavior, nutrient intake using a semi-FFQ questionnaire, physical activity using a questionnaire physical activity QuestionnaireAdult (PAQ- A). Secondary data in the form of the number of athletes per branch, the profile of the Youth Center Sports Obedience obtained from the administration section. Data processing in the form of editing, coding, entry, and cleaning. Data analysis used univariate, bivariate analysis (chi-square test and Fisher Exact Test) and multivariate test (multiple logistic regression). 


\section{Results}

It can be seen that most Youth Center athletes in West Sumatra Province are mostly (79.2\%) are men. The frequency distribution of age $59.4 \%$ is aged $16-19$ years, $39.6 \%$ are $11-15$ years old with an education level of $62.3 \%$ are Middle School, $37.7 \%$ are High School. The frequency distribution of athletes in the West Sumatra Province Youth Center Sports is 5.7\% athletic, 3.8\% bicycle racing, $4.7 \%$ judo, $16 \%$ wrestling, $4.7 \%$ karate, $11.3 \%$ pencak silat, $6,6 \%$ gymnastics, $17 \%$ soccer, $17 \%$ sepak takraw, $9.4 \%$ taekwondo and $3.8 \%$ boxing.

Table 1. Characteristics Distribution of Respondents

\begin{tabular}{cccc}
\hline \multicolumn{2}{c}{ Characteristics } & f & \% \\
\hline Sex & Male & 84 & 79,2 \\
& & & \\
\multirow{2}{*}{ Age } & Female & 22 & 20,8 \\
\multirow{2}{*}{ Education } & $11-15$ years & 43 & 39,6 \\
& $16-19$ years & 63 & 59,4 \\
& Junior high school & 66 & 62,3 \\
& & & \\
& Senior High scholl & 40 & 37,7 \\
\hline
\end{tabular}

Fitness level of Youth Center athlete Sports attitudes $78.3 \%$ are fit with a VO2Max value of at least $28.30 \mathrm{ml} / \mathrm{kg} /$ minute, maximum value of $61.30 \mathrm{ml} / \mathrm{kg} /$ minute, and an average value of $47.81 \mathrm{ml} / \mathrm{kg} /$ minute. The frequency distribution of athlete's eating behavior $57.5 \%$ is good. The eating behavior of athletes consists of 3 domains, namely knowledge, attitudes and habits. Knowledge of athlete's nutrition was $54.7 \%$ good, athlete's attitude was $56.6 \%$ positive, and eating habits were $46.2 \%$ good. For the nutritional status of athletes based on the Body Mass Index according to Age (BMI /Age) $81.1 \%$ is normal. Then for athlete physical activity $66 \%$ of athletes are very active, $34 \%$ of athletes are active, while athlete's energy intake is only $28.3 \%$ of which athletes are fulfilled as needed, for carbohydrates only $40.5 \%$ is fulfilled, fat is $57.5 \%$ sufficient, and $61.3 \%$ protein that is sufficient. Meanwhile the hemoglobin level of athletes was $92.9 \%$ normal. 
Table 2. Distribution for Univariate Respondents

\begin{tabular}{cccc}
\hline Variable & F & \% \\
\hline Fitness & Fit & 83 & 78,3 \\
Eating Behavior & Poor Fit & 23 & 21,3 \\
& Good & 61 & 57,5 \\
BMI-for-Age & Not Good & 45 & 42,5 \\
& Normal & 86 & 81,1 \\
Physical Activity & Abnormal & 20 & 18,9 \\
& Very Height & 70 & 66 \\
Energy Intake & Height & 36 & 34 \\
& Adequate & 30 & 28,3 \\
Protein Intake & In adequate & 76 & 71,7 \\
& Adequte & 65 & 61,3 \\
& Inadequate & 41 & 38,7 \\
Lemak Intake & Adequate & 61 & 57,5 \\
& Inadequate & 45 & 42,5 \\
Level Hemoglobin & Normal & 92 & 86,7 \\
& Abnormal & 14 & 13,3 \\
\hline
\end{tabular}

The results of the bivariate analysis for eating behavior with the level of athlete's fitness level found no association meaningful eating behavior with fitness. The statistical test obtained $\mathrm{p}$ value $>0.05$ (1.00). Then for BMI / Age with fitness levels there is a significant relationship between BMI / Age and fitness. The statistical test obtained $p$ value $<0.05$ (0.013). And the hemoglobin level with fitness level has a significant relationship with the fitness level of the athlete with a statistical test $\mathrm{p}<0.05(0.011)$.

The results of multivariate analysis found confounding effects (energy, carbohydrate, fat, protein intake) on the relationship of eating behavior with fitness. And for BMI-for-Age with fitness the confounding variable is energy intake and physical activity.

Tabel 3. Result of Multivariate Analysis

\begin{tabular}{llccc}
\hline Variabel & B & POR & $\mathbf{9 5 \%}$ CI & p-value \\
\hline BMI/Age & 3,431 & 30,914 & $2,924-326,882$ & 0,004 \\
\hline $\begin{array}{l}\text { BMI/Age*Phycical } \\
\text { activity }\end{array}$ & $-3,642$ & 0,026 & $0,001-0,700$ & 0,030 \\
& & & & \\
\hline
\end{tabular}




\begin{tabular}{lllll}
\hline Energy Intake & $-1,260$ & 0,284 & $0,087-0,929$ & 0,037 \\
physical activity. & 4,700 & 109,966 & $5,394-2,242$ & 0,002 \\
\hline
\end{tabular}

\section{Discussion}

The results of the research have been carried out on 106 adolescent athletes at the Youth Center in the West Sumatra Province of Sports that most athletic fitness levels are classified as good, with an average VO2max score of $47.81 \mathrm{~kg} / \mathrm{ml} /$ minute. Athletes who are said to be fit if the VO2max value is above $42.5 \mathrm{~kg} / \mathrm{ml} /$ minute. Athletes who have high $\mathrm{VO} 2 \mathrm{max}$ values will not get tired quickly and can play or compete optimally. The high value of athletes VO2max can be influenced by various factors, such as high intensity of exercise, balance and adequate nutrition, normal body composition, and so forth. In line with the research conducted by Wiwik Yunitaningrum in 2014 at the Youth Center of the Sports Law of the Province of West Kalimantan, $85 \%$ of the athlete's level of fitness was good. Athletes who are said to have good fitness if they have VO2Max values above $42.5 \mathrm{~kg} / \mathrm{ml} /$ minute. In line with the Wiwik Yunrum research in 2014, 85\% of the fitness of student athletes in West Kalimantan were classified as good and 10\% very good. In the study of Evi Komala dewi, et al., 2013 Ragunan athletes 'dormitory also found that athletes' fitness results were $63.6 \%$ classified as good. ${ }^{(4,5)}$

The high value of athletes VO2max can be influenced by various factors, such as high intensity of exercise, balance and adequate nutrition, normal body composition, and so forth. In line with the research conducted by Wiwik Yunitaningrum in 2014 at the Youth Center of the Sports Law of the Province of West Kalimantan, $85 \%$ of the athlete's level of fitness was good. Athletes who are said to have good fitness if they have VO2Max values above $42.5 \mathrm{~kg} / \mathrm{ml} /$ minute. In line with the Wiwik Yunrum research in 2014, 85\% of the fitness of student athletes in West Kalimantan were classified as good and $10 \%$ very good. In the study of Evi Komala dewi, et al., 2013 Ragunan athletes 'dormitory also found that athletes' fitness results were $63.6 \%$ classified as good. ${ }^{(4,5)}$

Athletes who have good VO2max abilities, will not get tired quickly and can take part in matches as long as they have maximum ability. Conversely, if the VO2Max value is low, the athlete will not be able to play or compete optimally. The higher the VO2max the athlete will have special endurance and stamina. The high value of athletes VO2Max can be influenced by various factors, such as the high intensity of exercise or physical activity performed by athletes, the balance and adequacy of Athletes's nutrients and so on. As in the results of the European Youth Heart Study, Vizcaino and Lopez studies show that adolescents whose physical activities are classified as active have good cardiovascular capacity as well. This is in line with the results of research conducted by Watulingas et al. physical exercise can increase the value of VO2max. ${ }^{(6,7)}$

On athlete's eating behavior, it was found that $57 \%$ of 106 athletes had good eating behavior. The eating behavior of athletes consists of 3 domains, namely knowledge, attitudes and eating habits. Knowledge of athlete nutrition more than half $54.7 \%$ is good, for the attitude of $56.6 \%$ of athletes have a positive attitude towards nutrition athletes, while eating habits $46.2 \%$ of athletes 
who have good eating habits. Eating behavior is influenced by various internal and external factors, internal factors, namely the value of trust, selection and meaning of food, psychosocial, health, self-concept and body image, while external factors are physical activity, peers, social culture, values and norms, fast food, mass media, and individual experiences. Knowledge of nutrition, attitudes and eating habits is a series of interrelated eating behavior domains. Increased knowledge, attitudes and skills interact with each other to form good eating behavior patterns. For this reason, nutrition knowledge needs to be improved, so that a positive attitude and good eating habits are created.

Meanwhile, from the aspect of eating habits, eating patterns. The diet for an athlete can be met with 3 meals (morning, afternoon and evening) and pay attention to the addition of certain types of food to provide energy during training and competition. However, the diet of athletes in these respondents has not paid attention to the quality of food that must be chosen based on nutritional value and balance of nutrients, where athletes consume food to eliminate hunger. This is indicated by the number of athletes who do not consume vegetables and in the portion do not pay attention to the portion of food consumed so that the adequacy and balance of nutrients is not fulfilled.

On the Body Mass Index by Age (BMI / Age) obtained from anthropometric measurements to describe the condition of the nutritional status of athletes, it was found $81.1 \%$ of the Youth Center athletes in West Sumatra Sports Alignment were normal. Normal nutritional status, caused by high awareness of athletes in maintaining a normal body weight. In line with Mustamin's research, et al. In 2010 found the nutritional status of student athletes based on BMI / Age obtained 90\% of athletes with normal nutritional status and 5\% fat and 5\% thin. In the results of Evy Komala's research, et al., 2013, it was also found that $97 \%$ of athletes had normal nutritional status. Then the results of the study of Oktyan Firman Bryantara in 2016 also found $56.67 \%$ of athletes with normal nutritional status, $43.33 \%$ fat. Body weight is related to strength, speed, endurance, agility, and appearance. For that weight, height and history of optimal nutritional status must be maintained ${ }^{(5,8,9)}$

Likewise for the condition of athlete's body fat must be considered. According to William, the loss of body fat deposits will increase biomechanical efficiency. The balance between BMI and body fat percentage must be maintained because according to Prista, et al, BMI status and body fat percentage are two things that influence each other on the risk of heart disease because the addition of body weight is associated with an increase in the proportion of body fat. The results of the analysis of the relationship between eating behavior and fitness level obtained $p$-value $>0.05(\mathrm{p}$ $=1.00)$, this value indicates that there is no significant relationship between eating behavior and fitness level. This is because eating behavior is not a direct aspect that affects fitness.

The results of the analysis of the relationship between BMI / Age and fitness level obtained pvalue $<0.05(\mathrm{p}=0.013)$, this value indicates a significant relationship between BMI / Age and fitness level. In line with the study of Oktian Firman it was stated that there was a significant relationship between BMI /Age and fitness level, where normal BMI / Age risk was 13.2 times fitter than fat BMI / Age. Thin athletes are at risk of damage to body tissue, while obese athletes cause a maximum reduction in body movement ability. In the results of the study of Oktian Firman Bryantara in 2016, it was also found that there was a significant relationship between BMI / Age and the athlete's fitness level, where normal BMI /Age risk was 13.2 times fitter than fat BMI / Age status. ${ }^{(9)}$

BMI status is the end result of a balance between foods that enter the body and the body's need for nutrients that are useful for the body's metabolism. BMI status that is lacking especially in adults will have an impact on one's physical fitness level. The right intake of nutrients will have an impact on the level of BMI that is good for athletes and will later affect the athlete's physical 
fitness level. If an athlete has a thin nutritional status, then it can be at risk of experiencing damage to body tissue, while an athlete who has a nutritional status that is fat, can cause a decrease in the body's ability to move optimally. ${ }^{(10)}$

A person's Body Mass Index (BMI) greatly determines a person's ability to carry out sports activities. Someone who has a normal BMI will be better able to do sports. High and low BMI values reflect the amount of energy reserves in the body. This reserve comes from the excess energy obtained from food. Someone who has more nutritional status (fat), according to Newton's second law will reduce the acceleration of motion. Fat nutrition status will lead to greater energy requirements in the aerobic system to carry out and carry out body movements. ${ }^{(11)}$

Therefore, being overweight will generally cause much earlier fatigue. While someone who has a thin nutritional status, will experience a decrease in strength, flexibility and dexterity and decreased cardiovascular endurance.

Then for the results of the confounding test of the relationship between eating behavior and the athlete's fitness level, it was found that the influencing variable was energy intake. From the final model it can be explained that good eating behavior has a chance of fitness level 0.8 times compared to athletes who do not have good eating behavior after being controlled by energy intake. As for the relationship of BMI / Age with the athlete's fitness level, it was found that the influencing variables were energy intake and physical activity. From the final model it can be explained that normal BMI / Age has a good chance of fitness level 30 times compared to athletes who have abnormal BMI /Age after being controlled by variable energy intake and physical activity.

Physical activity is movements carried out by skeletal muscles. Athletes who are trained in regular sports activities will have muscles that are stronger, more flexible and have good cardiorespiratory resistance so that it will affect the fitness level. Physical activity is a function of fitness so someone who does not have adequate fitness, productivity will also not be as good as someone who has a good fitness category. Likewise, someone who does not carry out adequate physical activity will not have good fitness. Regular and varied physical activities can have an effect on increasing cardiorespiratory endurance, decreased heart rate and blood pressure, increased work efficiency of the heart muscle, increased endurance in physical activity, increased muscle strength and increased metabolism. ${ }^{(12)}$

Then the energy intake also affects the athlete's fitness level, that the provision of optimal nutrition can help sports achievement by maximizing energy savings through regulating the calorie intake of athletes' food. Use of glucose / muscle glycogen increases sharply with increasing exercise. In the 40th minute glucose use reaches 7-20 times compared to rest, depending on the intensity of the exercise. 25 Carbohydrates provide $80 \%$ contribution to energy and if the length of the exercise is extended, carbohydrate reserves are reduced, fat is the main source.

At the intensity of the exercise with a VO2Max level of less than $50 \%$, the body works aerobically and fat is an energy source. At the VO2Max level 60-65\% of energy from carbohydrates and fats is less balanced. The intensity of VO2Max is above $65 \%$, carbohydrate is the main energy source. VO2Max capacity as an indicator of athlete fitness in sports science is also often used as a term of aerobic capacity, namely the use of maximum oxygen in the fastest tempo because an athlete can use oxygen during exercise. In this study it appears that VO2Max capacity is influenced by physical activity and body composition (body mass and fat mass), energy intake.

This is in accordance with what was revealed by Pate that the habits of activities and background in sportsmanship training can affect the value of VO2Max and it is now believed that muscle metabolic functions adjust to resistance training and increased VO2Max. Programmed and measurable exercises can provide an increase in VO2Max capacity between $10 \%-20 \%$ that 
physical fitness especially aerobic capacity can be increased through aerobic exercise by taking into account factors such as exercise intensity, frequency of exercise and length of training in the training zone. The heavier the training load given the greater the effect obtained, the recommended intensity is between $72 \%-87 \%$ maximum pulse $(220$-age). The recommended frequency of exercise is 3-5 times per week and it is not recommended to do sports in a row without giving the body a chance to rest. The recommended length of practice is between 20-30 minutes to warm up. In addition to these factors, heart function, aerobic muscle metabolism, body fat, heredity, gender also affect fitness. ${ }^{(13,14)}$

\section{Conclusion}

Most athletes in West Sumatra Province have a good level of fitness. There is no significant relationship between eating behavior and athlete's fitness level $(\mathrm{P}=1.00)$. There is a significant relationship between BMI / Age and athlete's fitness level $(\mathrm{P}=0.013)$. The variable that influences the relationship between eating behavior and fitness is energy intake. Whereas the BMI / Age with the athlete's fitness level is physical activity and energy intake.

\section{Recommendations}

In further research, it is expected to be able to assess the effectiveness of sports nutrition education on the knowledge and eating habits of athletes with experimental research designs, as well as to examine more deeply about food administration and the quality of the menu presented.

\section{References}

1. Afriwardi. Ilmu Kedokteran Olahraga. Jakarta: EGC; 2010.

2. KementerianKesehatan, RI. Pedoman Gizi Olahraga Prestasi. Jakarta; 2013

3. Kemenpora. Data Informasi Prestasi Dan Cabang Olahraga Unggulan. Kementerian Pemuda Dan Olahraga RI; 2014.

4. Yunitaningrum, Wiwik. Kemampuan Volume Oksigen Maksimal Atlet Pusat Pendidikan dan Latihan Pelajar Sepak Takraw Kalimantan Barat. Media Ilmu Keolahragaan Indonesia. 2014;Vol 2

5. Dewi EK, Kuswari M. Hubungan Asupan Zat Gizi Makro Dan Status Gizi Terhadap Kebugaran Atlet Bulu Tangkis Jaya Raya Pada Atlet Laki-laki dan Perempuan Di Asrama Atlet Ragunan Tahun 2013. J Nutr Diaita. 2013; Volume 5.

6. Vizcaino VM and Mairena Sanchez-Lopez. Relationship Between Physical Activity and Physical Fitness in Children and Adolescent. 2008. Revista Espanalo de Cardiologia (English Edition) ; Volume 5

7. Watulingas 5. Syafrizar, Welis W. Gizi Olahraga. Malang: Wineka Media; 2009.

8. Mustamin, KU dan Ayu SD. Tingkat Pengetahuan Gizi, Asupan dan Status Gizi Atlet Di Pusdiklat OlahragaPelajar Sudiang Kota Makasar. 2010. Media Gizi Pangan ;Volume IX

9. Bryantara Okta F. Faktor Yang Berhubungan Dengan Kebugaran Jasmani (Vo2MAks) Atlet Sepak Bola. J Epidemiol. 2016; Volume 4.

10. Supariasa DN, Bakri B, Fajar I. Penilaian Status Gizi. Jakarta: EGC; 2012.

11. Achadi EL. Gizi dan Kesehatan Masyarakat. Jakarta: PT Raja Grafindo Persada; 2010.

12. Anderson J.Human Nutrition Healthy Option for Life.Burlington: Jones \& Bartlett Learning;2014

13. Arsani NLK, Agustini NNM, Sudarman IN.Manajemen Gizi Atlet Cabang Olahraga Unggulan di 
Kabupaten Buleleng.J Sains dan Teknologi.2014;Vol3.

14. Ferdinan TP.Hubungan Aktifitas Fisik Harian dengan Tingkat Kebugaran Jasmani Siswa SMPN2 Candi Sidoarjo.J Pendidikan Olahraga dan Kesehatan.2017; Volume3. 